\title{
Artes, performatividade, crise generalizada e necropolítica
}

Cassiano Sydow Quilici

Universidade Estadual de Campinas

Campinas, SP, Brasil

cassianosyd@uol.com.br

orcid.org/0000-0003-0042-5378

\section{Eduardo Okamoto}

Universidade Estadual de Campinas

Campinas, SP, Brasil

okamoto@unicamp.br

orcid.org/0000-0002-0376-9611

\section{Juliana Martins Rodrigues de Moraes}

Universidade Estadual de Campinas

Campinas, SP, Brasil

jumoraes@unicamp.br

orcid.org/0000-0003-0623-8178

A publicação da presente edição da revista Conceição|Conception, reveste-se, para nós, de um significado muito especial. Já o convite feito à Profa. Dra. Ileana Dieguéz Caballero para integrar a equipe como Editora Convidada do Dossiê "Artes, performatividade, crise generalizada e necropolílitica" expressa o desejo de abrir a publicação para reflexões mais amplas e sobre o lugar das artes e da performatividade como força cultural, num contexto tão complexo e difícil como o que atravessamos. Entendemos que não é possível mais ignorar as urgências de nosso tempo, em especial a crise dos modos hegemônicos de existência que se alastraram pelo planeta, pautados, muitas vezes, na destruição do meio ambiente, superexploração econômica, guerras culturais e políticas veladas e declaradas de extermínio, especialmente nas zonas "periféricas" do mundo. Como reconsiderar os saberes artísticos e as potências criativas que estes mobilizam para fazer frente a uma situação inédita, reinventando as ações artísticas e culturais enquanto forças reconfiguradoras da nossa vida pessoal e coletiva?

Neste sentido, as colaborações de autores e autoras da América Latina, ao lado de outras, oriundas do Brasil, têm uma importância fundamental na discussão aqui proposta. A construção de outras formas de perceber, pensar e propor, partindo da singularidade de nossas experiências, em diálogo com o pensamento vivo desenvolvido na Europa e Estados Unidos, é um desafio que se impõe, se desejamos lidar com as marcas coloniais que nos atravessam. Neste momento, enfatizamos que a escuta a 
vozes de diferentes tradições, especialmente as de matrizes indígenas e afro, é fundamental para a reativação da imaginação política, a renovação das ideias e o aprofundamento dos saberes performativos. Esperamos que esse processo possa se aprofundar, sendo essa publicação um estímulo para novos debates, encontros e parcerias.

Por fim, a dimensão adquirida pela pandemia de COVID-19 configura uma situação imprevisível, gerando perplexidades e atitudes que vão da pura e simples denegação ao uso político da situação para o aprofundamento dos mecanismos de controle e desmobilização da população. Diante dos enigmas colocados pelas "pestes", o pensamento científico e crítico pode andar de mãos dadas com as investigações artísticas que revelam aspectos subjetivos, simbólicos e a dinâmica dos afetos desencadeada pela nova situação. Estes são os "saberes pandêmicos", evocados por Ileana no seu belo texto de abertura, que, diante do inusitado, desenvolvem com paciência, rigor e sensibilidade, caminhos possíveis de compreensão, cuidado e recriação das nossas formas de ser e estar juntos.

Em tempo: a partir de 2020, a revista Conceição|Conception, adotou o sistema de publicação contínua. Neste modo de proceder, não há fascículos, nem periodicidade, como praticamos até 2019. Os artigos são publicados conforme são aprovados pelo processo de avaliação por pares. 